\title{
КОНЦЕПТОТ ЗА РЕФОРМИ НА БЕЗБЕДНОСНИОТ СЕКТОР ВО РЕПУБЛИКА МАКЕДОНИЈА
}

\section{Крайка сояржина}

Реформитие на безбеяносниой секитор се широко йрифайен концейй кој се оянесува на физичкайа и йехничкайа йрансформачија на безбеяноснийе инстиитуции во насока на йояобрување на начините на рабойа и функционирање на безбеяносниой секитор. Основниой кончейй, ілавно, се базира на иринцийой на чивилна конитрола ная военийе и безбеяносните сили, шито во основа значи оека ке іи найрави йоояіоворни и йойрансйаренйни во нивнайа рабойа. Теорейскайа ексйликачија на йруяой е насочена најнайрео кон уйвроување на йойребайа оо реформи на безбеяносниой секитор во нашайа оржава, вйоро, кон можниие йоообри начини за соояветина итрансформачија на безбеяноснитие ситрукитури и,

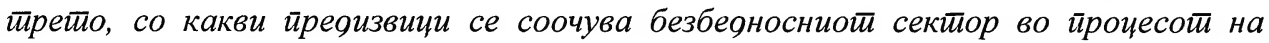
реформи.

\section{Клучни зборови: РЕФОРМИ, КОНЦЕПТ, БЕЗБЕДНОСЕН СЕКТОР, РЕДЕФИНИРАЊЕ, ТРАНСФОРМАЦИЈА}

\section{1. Ойшйо за реформитие}

Реформите во безбедносниот сектор' се витални за глобалниот мир и безбедноста, особено во постконфликтните држави и градењето на нацијата. Во слабите држави, конструкцијата и реконструкцијата на безбедносниот сектор е предуслов за развој, бидејќи ниту една друга реформа - политичка, економска или социјална - не може да се вкорени без постигнување соодветно ниво на безбедност. Дополнително, помошта на слабите држави при заздравувањето е критична за глобалната безбедност, бидејќ тие може да предизвикаат хроничен меѓународен проблем; да поттикнуваат регионална нестабилност која ќе резултира со хуманитарна трагедија; да создадат подрачја за тренинг и бази за операции на терористите; и помагање на меѓународните криминални организации што шверцуваат наркотици, луѓ, лесно оружје, оружје за масовно уништување и други незаконити продукти

\footnotetext{
${ }^{1}$ Безбедностиот сектор е дефиниран како оние државни организации што имаат овластување да употребат или да наредат употреба на сила, притворање и затворање, да ја заштитат државата и нејзините граѓани, како и оние цивилни структури што се одговорни за менаџмент и надзор на безбедностиот сектор. Дефиницијата, исто така, ги вклучува и воените и паравоените сили, разузнавачките агенции, полицијата, граничните служби, царината, правниот систем, парламентарниот, правниот и административниот менаџмент и надзорните органи (www.stabilitypact.org), односно безбедносниот сектор може да се подели на три столба, и тоа: групи со мандат да употребуваат инструменти на насилство - воени, паравоени и полициски сили; институции со улога во менаџирање и мониторинг на безбедносниот сектор - цивилни министерства, парламенти и невладини организации; тела одговорни за гарантирање на владеењето на законот - судството, казнениот систем, бранители на човекови права, во овие области овие тела се посебно слаби, таа улога ѝ припаѓа на меѓународната заедница.
} 
и услуги. Конечно, компетентниот и автохтон безбедносен сектор е есенцијален за излезната стратегија од скапите мировни мисии.

Во основа, поимот реформи во безбедносниот сектор се смета дека станува актуелен во доцните деведесетти години на минатиот век, како резултат од потребата за демократизација на општествата што излегоа од Советскиот блок и, секако, бројни држави од Југоисточна Европа, особено од Балканот во тој период. Тоа се однесува на фактот дека овие општества поминаа низ целокупна трансформација на речиси секоја државна институција, што претходно била структурирана и администрирана во социјалистички манир и во тоталитарен режим (Pavliuk, O., Tsintsadze, I.,K.: 2004, стр. 20). Значи, падот на Берлинскиот sид и колапсот на Источниот блок ја промени оваа реалност. Но, некаде во 2002 година, овој концепт на реформи во безбедносниот сектор прв пат беше прифатен со сета своја сериозност и беше споменат во Извештајот за хуман развој на ОOH (UNDP's Human development report). Исто така, не треба да се заборави дека реформите на безбедносниот сектор беа и реална потреба и на западноевропските држави особено во делот на зголемената потреба од трансформација на безбедносните сили и редукција на трошоците (Wulf, Н., стр. 340).

Сепак, потребата од трансформација на безбедносните институции може да се пронајде дури и во 1960 година со примерите на воени удари во Африка, во Азија и во Јужна Америка (Wulf, H., стр. 340). Исто така, искуствата покажуваат дека потребата од контрола на воената потрошувачка, моделирањето на нејзината улога и одговорноста во општествата, изразена преку постконфликтно градење на државата и превенција на корупцијата, е појава која е присутна и во развиените држави со демократска традиција кои се напредни во безбедносната и воената опрема и тактика, како и во земјите во развој и во земјите погодени од конфликт на кои им е потребна повторна изградба на институциите.

Во овој контекст, значаен факт што вреди да се спомене е аргументацијата дека во постконфликтните општества реформите во безбедносниот сектор имаат тенденција да извршат транзиција и преод (како во државниот, така и во приватниот), кој ќе се однесува на спроведување безбедност (како уставна обврска и во согласност со владеењето на правото) за граѓаните и за вредностите. Примерите во субрегионот во Западна Африка покажуваат дека примарна процена на ситуацијата со националната безбедност во внатрешна, во политичка форма, како и во меѓународните конекции е суштинска при креирањето платформа за реформите во безбедносниот сектор, која ќе одговара на конкретната држава и ке биде долгорочно одржлива и ефективна (Mühlmann, Т. 2008).

\section{2. Сйецифичен конйексй на реформите}

Во практика, реформите на безбедносниот сектор значително варираат според контекстот на специфичните реформи. Постои општа согласност дека не постои универзален модел на реформи на безбедносниот сектор и дека, во принцип, секоја држава која ги прифаќа реформите во безбедносниот сектор е специјален случај, па оттаму произлегува различниот контекст на реформите. 
Сепак, за аналитички цели, може да биде издвоен широк контекст на реформите во безбедносниот сектор што содржат низа аргументи во зависност од критериумот за категоризација. Во основа, може да бидат диференцирани три вакви широки контексти на реформи во безбедносниот сектор за кои ке се дискутира и секој од нив одразува различен пристап за реформата.

Прво, реформите во безбедносниот сектор се прифатени од страна на меѓународните развојни донатори, како инструмент за подобрување на ефикасноста и ефективноста за поддршка на развојот.

Второ, реформите во безбедносниот сектор станаа алатка за олеснување на практичната координација и концептуална интеграција на одбранбените и на безбедносните сили во поставторитарните држави, особено во посткомунистичките држави во Централна и во Источна Европа, но и пошироко.

Трето, реформите во безбедносниот сектор се стекнаа со најпрактична релевантност во контекст на постконфликтна реконструкција на т.н. „пропаднати држави“ и држави што излегуваат од насилни внатрешни или меѓудржавни конфликти, како што е евидентно и од широкиот спектар случаи како што се Авганистан и Ирак. И во двата случаја, од страна на мировниците и развојните актери на реформите во безбедносниот сектор се гледа како на клуч за успех во целокупните ангажмани за реконструкција. Реконструкцијата на безбедносниот сектор, односно реформите во безбедносниот сектор во постконфликтен контекст, изобилува со бројни специфични прилози што се разликуваат од другите рамки на реформите во безбедносниот сектор (Ekengren, M., Simons, G., 2011, стр.25).

Основата за успех на реформите во безбедносниот сектор е холистичкиот (меѓуповрзаниот, сеопфатен) пристап до нивните димензии и овозможување услови за да може да напредува (Christensen, T., Lægreid, P., 2007). Политичката реформа вметната во реформите во безбедносниот сектор означува дека вооружените и безбедносните сили треба да бидат политички делигимитирани, во насока во која нема да се штитат одредени режими или елити, туку демократски и институционално, со легитимни институции, ке се штитат граѓаните и нивните права, како и вредностите на државата. ${ }^{2}$

Генерално, реформите во безбедносниот сектор треба да бидат усвоени во форма на нацрт-закон или легислатива која е усвоена од страна на политичките предводници во државата. Реформите треба да се спроведуваат како сеопфатна програма создадена од одбрани парламентарни претставници кои се задолжени за одбрана и за безбедност, личности со искуство и со експертиза во тоа поле. Оваа програма треба да биде советувана од страна на професионалци од безбедносниот сектор, што значи дека високи претставници од вооружените сили на државата и од експертската заедница треба да бидат вклучени во создавањето на оваа специфична платформа. Многу е значајно одлуките да бидат конзистентни и ефективни на долг рок. На пример, ако едно политичко водство усвои закон

\footnotetext{
${ }^{2}$ https://books.google.mk/books?hl=en\&lr=\&id=_HEjrxWAihoC\&oi=fnd\&pg=PP5\&dq=political+aspects+of + security + sec tor+reform\&ots=eSspSDT_zc\&sig=HNNrIhIFhIVErfu0vLB-

Q7B42wQ\&redir_esc=y\#v=onepage\&q=political\%20aspects\%20of\%20security\%20sector\%20reform\&f=false (посетена 9.2.2015).
} 
што ќе ги трансформира безбедносните сили во демократски, транспарентен, државен ентитет кој ќе спроведува безбедност за сите свои граѓани, промена во политичкиот менаџмент (на пример, ако владејачката политичка партија ги изгуби наредните избори), овие реформи не смеат да бидат запоставени и стопирани поради бојкот на претходното политичко претставништво (што е типично за нови демократии и новите поставторитарни држави). Тоа се реформи што се над дневнополитичките превирања, односно тие се во функција на самата одбрана и безбедност на државата.

\section{3. Некои асйекйи на реформийе на безбеgносниой секӣор во Рейублика Макеоонија}

Во Република Македонија, иако се направени одредени чекори од реформите со безбедносниот сектор, сепак, реформите претставуваат едно релативно ново прашање што отвора простор за понатамошни подобрувања и усовршувања. Реформите треба да се вклопуваат во една поширока општествена рамка, но притоа не треба да се заборави и на политичкиот контекст. Се смета дека безбедносниот сектор сѐ уште е поврзан со лошите навики на партиската контрола на одредени сегменти од безбедносниот сектор. Тоа создава проблеми во приспособувањето, при што влијае на општеството и се одразува на различни начини. За Република Македонија, која нема голема демократска традиција, главната цел на реформите е формирање силни безбедносни структури, воспоставување на системот на повеќегодишно планирање, програмирање и буџетирање во сите сектори, поголема координација на безбедносната заедница и зајакнување на демократската контрола врз безбедносниот сектор.

Генерално, постои убедување дека нема надеж дека некоја реформа би можела да успее без да се заплетка во неколку клучни проблеми. Еден од најголемите проблеми е врзан за правната празнина во однос на координацијата помеѓу институциите, службите и телата што се занимаваат со внатрешната безбедност и безбедносните процени на земјата и јасно е дека слабата страна е недостаток на подоследни и постојани канали на комуникација и соработка помеѓу клучните актери во безбедносниот сектор (Ванковска Б., 2003, стр. 2829).

Следната иницијална анализа се однесува на организациските и функционалните елементи што влијаат врз обемот и ефикасноста на постојните, но модификувани безбедносни структури. Ова посебно е важно за да се зајакне организациската структура и, секако, функционалноста на безбедносниот систем.

Клучно е и прашањето за намалување на бројот на вработени како своевидна потреба од редуцирање на бројот на персоналот паралелно со редукцијата на амортизираната и застарена опрема. Решението се гледа условно преку „истиснување“ на одредени бројки искажани во бројниот сооднос на вработените и замислената организациска структура, но, сепак, ваквите активности треба да го постигнат потребниот баланс преку изнаоѓње разумно ниво на капацитети кои истовремено ќе бидат доволен одговор за справување со ризиците и заканите за мирот и безбедноста. 
Следниот проблем што придонесува да се отежнат реформите е непостоењето заеднички дијалог меѓу цивилниот и безбедносниот сектор. За успешно спроведување на реформите, предуслов е воспоставување ефикасна комуникација помеѓу цивилниот и безбедносниот сектор, која може да ја зајакне довербата помеѓу овие две компоненти и позитивно да се одрази врз динамиката на реформите. Непосредната комуникација и соработка на овие два сектора придонесува за интензивирање на напорите за изнаоѓње решенија што ќе бидат во функција на безбедносниот сектор.

\section{Заклучок}

Денес, не постојат универзален метод и шема што може да бидат применети на општества што закрепнуваат од конфликт или на транзициски држави каде што претходните авторитарни и воени режими треба да бидат заменети со демократски институции што ќ поседуваат квалитети, како што се владеење на правото и транспарентност во нивните активности и буџети.

Затоа самиот концепт, иако има универзални точки што се однесуваат на управувањето со самата држава и има широки аспекти, сѐ уште има потреба да биде приспособен на конкретните домашни услови, со цел да биде функционален и одржлив. Само на тој начин ресурсите од внатрешните буџети, како и фондовите од донаторите однадвор може да бидат целосно употребени и соодветно лоцирани. Затоа што доколку процесот на реформи во безбедносниот сектор налета на неконзистентности, може да трае со години, без да биде оперативен и долгорочно ефективен.

Клучен предуслов за успешни реформи во безбедносниот сектор е политичкото раководство, безбедносните институции, како и експертите од министерствата поврзани со безбедноста, заедно со други релевантни тела што спроведуваат безбедност, да го разберат и да го прифатат концептот за реформи во безбедносниот сектор како неопходност. Тие треба да го имплементираат и да го спроведат во своите обуки, во своите функции и активности, како и понатаму да го пренесат концептот на пониските нивоа во хиерархијата. Тоа значи инкорпорирање на принципите за демократска контрола над безбедносните институции, почитување на владеењето на правото на секое ниво на менаџмент, почитување на човековите права на вработените и на граѓаните на конкретните општества. 


\section{Литерайура}

Бакрески О., Коороинаиија на безбеяноснайа заеянииа на Рейублика Макеяонија, Филозофски факултет, Скопје, 2005

Бакрески О., Конйрола на безбеяносниой секӣор, Филозофски факултет и Аутопринт, Скопје, 2012

Beeson, M., Bellamy, A.: Securing South-East Asia. The politics of Security Sector Reform. Routledge, Taylor \& Francis Group. 2008.

Christensen, T., Lægreid, P.: The Whole-of Government Approach to Public Sector Reform. PAR, Volume 67, Issue 6. 2007.

David Law, Intergovernmental Organizations and security Sector Reform. PDF.

Defence and Security Sector Governance and Reform in South East Europe: Insights and Perspectives, Volume I, Albania, Bulgaria, Croatia, Trapans Jan and Fluri Philipp (eds.), Geneva Centre for the Democratic Control of Armed Forces, Genneva/Belgrade, 2003

Ditrich F., Nonmilitary Aspects of Security: A Systems Approach, UNDIR, 1993

Doro, E.: Reviewing the Debates on Security Sector Reform in Zimbabwe and Locating the Role of the Legislature.

Gyarmati I.; Vesel S.(eds.), Security Sector Governance in the Western Balkans 2004, Nomos Verlagsgesellschaft, Baden-Baden, 2004.

Ekengren, M., Simons, G.: The Politics of Security Sector Reform. Ashgate Publishing Limited, 2011

Edmunds T., Security sector reform in transforming societies: Croatia, Serbia and Montenegro, Manchester Unuiversity Press, Manchester, 2007

Fluri, P. H., Gustenau, E. G., Pantev, I. E.: The Evolution of Civil Military Relations in South-East Europe. Continuing Democratic Reform and Adapting to the Needs of Fighting Terrorism. Physica - Verlag Heidelberg, 2005.

Hans Born and Albrecht Schnabel. Security Sector Reform in Challenging Environments. DCAF

Hunggi, H.: Conceptualizing Security Sector Reform and Reconstruction. Pdf.

Huhn, J. S.: Rebuilding the Security Sector in Post-Conflict Societies: Perceptions from Urban Liberia and Sierra Leone. DCAF, Lit- Verlag Dr. W. Hopf, Berlin, 2010.

Jackson, P.: SSR and Post-conflict reconstruction: The Armed Wing of State Building. Pdf.

Johanna Mendelson Forman "Promoting Civil Society in Good Governance: Lessons for the Security Sector".

Post Cold War Defense Reform, Library of Congress Cataloging-in-Publication Data by Brassey`s, Inc. 2002

McFate, Sean. Securing the Future. A Primer on Security Sector Reform in Conflict Countries. USIP, 2008. PDF. 
Mühlmann, T.: Police Restructuring in Bosnia and Herzegovina: Problems of Internationally Led Security Sector Reform. Journal of Intervention and State Building. Volume 2, Issue 1. 2008.

Pavliuk, O., Tsintsadze, I., K.: The Black Sea Region: Cooperation and Security Building. EastWest Institute, 2004

Schmidt, H. J.: Military Confidence Building and Arms Control in Unresolved Territorial Conflicts. PRIF-Reports No. 89 
Oliver BAKRESKI

\title{
THE CONCEPT OF SECURITY SECTOR REFORM IN THE REPUBLIC OF
} MACEDONIA

\begin{abstract}
Summary
The security sector reforms are a broadly accepted concept which regards the physical and the technical transformation of the security institutions in the direction of improvement of the methods of work and function of the security sector. The fundamental concept is mainly based on the principle of civil control over the military and security forces, which basically means that it will make them more accountable and transparent in their work. The theoretical explication of this paper is primarily focused on designating the need for reforms of the security sector in our country, secondly, toward the better ways for an appropriate transformation of the security structures and third, what kind of challenges the process of security sector reform faces.
\end{abstract}

Keywords: REFORMS, CONCEPT, SECURITY SECTOR, REDEFINING, TRANSFORMATION 